This item was submitted to Loughborough's Research Repository by the author.

Items in Figshare are protected by copyright, with all rights reserved, unless otherwise indicated.

\title{
Critical perspectives on the globally mobile professional and managerial class
}

PLEASE CITE THE PUBLISHED VERSION

http://dx.doi.org/10.1108/cpoib-10-2014-0043

\section{PUBLISHER}

(c) Emerald Group Publishing Ltd.

\section{VERSION}

AM (Accepted Manuscript)

\section{PUBLISHER STATEMENT}

This work is made available according to the conditions of the Creative Commons Attribution-NonCommercialNoDerivatives 4.0 International (CC BY-NC-ND 4.0) licence. Full details of this licence are available at: https://creativecommons.org/licenses/by-nc-nd/4.0/

\section{LICENCE}

CC BY-NC-ND 4.0

\section{REPOSITORY RECORD}

McKenna, Steve, M.N. Ravishankar, and David Weir. 2019. "Critical Perspectives on the Globally Mobile Professional and Managerial Class". figshare. https://hdl.handle.net/2134/19008. 


\section{Abstract}

\section{Purpose:}

The purpose of this paper is to introduce the papers in the special issue.

\section{Design/methodology/approach}

A general description of each paper in the special issue is provided. The introduction highlights the need for more research into the broad topic of the global elite.

\section{Findings}

Research in the social sciences uses a very broad definition of the global elite. It would be helpful in critical management and organization studies and critical international business research, to begin to identify important and key research areas that enable a more critical investigation of who the global elite are and how they might be studied.

\section{Originality/value}

The paper introduces five diverse papers that deal with issues pertaining to a global elite and transnational capitalist class. 


\section{Critical perspectives on the globally mobile professional and managerial class}

The power elite is composed of men (sic) whose positions enable them to transcend the ordinary environment of ordinary men and women; they are in positions to make decisions having major consequences (Wright Mills, 1956, p. 3).

In recent years important contributions have been offered to the discussion concerning global capitalism, and also within this context, about the networks and mobility of the contemporary power elite or transnational capitalist class. An important element of this work is the idea that the neoliberal globalized world is sustained and perpetuated through the agents and functionaries of neoliberal global capitalism (Carroll, 2010; Robinson, 2004; Robinson, 2012; Sklair, 2001). For example, a number of emerging literatures are engaging with how this global system is constructed and enacted (Dardot and Laval, 2013; Panitch and Gindin, 2012). There is also work on the global elite (Freeland, 2011; Harvey and Maclean, 2008; Rothkopf, 2008; Unruh and Cabrera, 2013); network capital (Richardson, Kakabadse, and Kakabadse, 2011); nomadic capital (Braidotti, 2011); global contact zones (Yeoh and Willis, 2005); global elite conferences (Carroll and Sapinski, 2010; Richardson et al, 2011); global philanthropy (Newland, Terrazas, and Munster, 2010); celebrity humanitarianism (Bell, 2013; Cooper, 2008; Kapoor, 2012) and; philanthrocapitalism (Bishop and Green, 2008). In many ways this global elite or transnational capitalist class constitutes a "semi-organized network of individuals from business, government, academia, civil society and the media” (Andersson and Calvano, this issue), as well

as a network of formalized institutions, who seem to be organizing the global economy in a particular direction.

The development of global capitalism has stimulated an interest not only in identifying a/the global elite, but also in their means of networking and in the connections that they forge. There are important questions being asked not only about the 'super elite' but also those who constitute the next level. Sklair (2001) for example, argued that the transnational elite consisted of four elements: those who own and control transnational corporations; global politicians and 
technocrats; globally mobile professionals and a group of people engaged in global trade, media and advertising. Rothkopf (2008) suggested that influential government leaders; the highestranking individuals in the biggest corporations; high-ranking military personnel and others constituted the global elite. In short, there remain many questions to be asked and answered about, what might be broadly termed, the transnational capitalist class; not least of which is the question of whom it is constituted. Both Sklair's (2001) and Rothkopf's (2008) constituents of the transnational elite or capitalist class are suggestive of an enormous range of topics for potential research and study. Where can we begin?

In this special issue five distinctive and critical contributions draw our attention to a range of issues in relation to a transnational elite and a globally mobile professional and managerial class; each of the contributions deal with important groups and questions that relate to a 'transnational elite'. Andersson and Calvano investigate the 'Bono effect' and more specifically, the ideological aspect of celebrity philanthrocapitalism. What is particularly important in their consideration of celebrity 'aid' is the extent to which it usurps the important role of nations coming together in mutual support and recognition. Celebrities become part of the elite that direct the social as well as economic aspects of globalization and in so doing perpetuate and support a neoliberal globalist agenda.

Fisher's contribution highlights the manner in which 'femininity' has been historically and contemporaneously appropriated by the financial sector in the US to promote a distinctive type of financial capitalism. This is particularly the case post the 2008 financial crisis. Fisher shows how the 'female elite' of the global financial industry have used and been used by the industry to project a more 'caring' image of the financial sector. Fisher implies that this is simply a ruse to make the financial sector more palatable to the world at large, but in reality represents a continuation of the dominance of financial capitalism. 
The contributions of Thomson and Jones and Hilde and Mills investigate another dimension of the global professional elite. Thomson and Jones consider immigrant accountants in Canada through the postcolonial concept of mimicry. Globally mobile accountants constitute part of the global elite as key functionaries of capitalism. However, the movement of accountants from peripheral nations to metropolitan centres, such as Canada, is often subject to neocolonial stereotypes, where the accounting profession in Canada will function to find ways of excluding immigrants from professional practice. In Canada, for example, additional 'credentials' are established as a mechanism of exclusion. This requires immigrants to engage in mimicry in order to become acceptable in the Canadian context. Thomson and Jones identify three forms of mimicry in which immigrant accountants engage: reluctant mimicry, frustrated mimicry and consummate mimicry. This close investigation of immigrant accountants in Canada makes a significant contribution to the concept of mimicry as a tool for empirical study.

Hilde and Mills investigate Hong Kong immigrants to Canada. In this paper the immigrants interviewed are part of the global professional elite who have moved to Canada but find it difficult to maintain their elite status in the new context. Using critical sensemaking the authors show how immigrants come to accept their social and economic exclusion. The authors also highlight how the programmes designed to integrate new immigrants to Canada are often counter-productive and operate to exclude rather than include immigrants. It is also, however, ironic that Hong Kong immigrants who enjoyed elite status in Hong Kong, which included Filipina maids and other trappings of high status, are also concerned with the loss of this status in a Canadian context. This paper shows how the idea of a global elite and global elite mobility is influenced by its intersection with race.

Goxe and Belhoste investigate how a global elite group from France have developed a discourse to exclude entry into this global elite. There is a strong Bourdieusian element to this paper as an elite group discursively utilize elements of cultural capital to exclude small business 
people in particular from gaining access to a global context. They do this through dismissal and denigration of the education, language skills and ‘sophistication' of the excluded.

Together the papers in this special issue offer a diverse range of investigations of the global elite. Their diversity indicates the width of possible ways in which a global elite and globally mobile professionals might be studied and highlights the substantial opportunities that exist to research such groups from a critical perspective. We hope that this special issue stimulates others to further develop critical research agendas on the topics of the global elite, the transnational capitalist class and globally mobile professionals. 


\section{References}

Bell, K. M. (2013), "Raising Africa?: celebrity and the rhetoric of the white savior", Journal of International Multidisciplinary Studies, Vol. 10 No. 1. pp.1-24.

Bishop, M., \& Green, M. (2008), Philanthrocapitalism: How the Rich can Save the World, A and C Black, London.

Braidotti, R. (2011), Nomadic Theory, Columbia University Press, New York, NY.

Carroll, W. K. (2010), The Making of the Transnational Capitalist Class, Zed Books, London

Carroll, W. K., \& Sapinski, J. P. (2010), "The global corporate elite and the transnational ploicyplanning network, 1996-2006: a structural analysis", International Sociology, Vol 25 No. 4, pp. 501-538.

Cooper, A. (2008), Celebrity Diplomacy. Paradigm, Boulder, CO

Dardot, P., \& Laval, C. (2013), The New Way of the World: On Neoliberal Society, Verso, London.

Freeland, C. (2011). The rise of the new global elite. The Atlantic, January/February.

Harvey, C., \& Maclean, M. (2008), "Capital theory and the dynamics of elite business networks in Britain and France", Sociological Review, Vol. 56 No. S1, pp. 103-120.

Kapoor, I. (2012), Celebrity Humanitarianism: The Ideology of Global Charity, Routledge, London. 
Newland, K., Terrazas, A., \& Munster, R. (2010), Diaspora philanthropy: Private Giving and Public Policy, Migration Policy Institute, Washington D.C.

Panitch, L., \& Gindin, S. (2012), The Making of Global Capitalism, Verso, London.

Richardson, I., Kakabadse, A., \& Kakabadse, N. (2011), Bilderberg People, Routledge, Oxford:

Robinson, W., I. (2004), A Theory of Global Capitalism, Johns Hopkins University, Baltimore, MD.

Robinson, W. I. (2012), "Global capitalism theory and the emergence of transnational elites", Critical Sociology, Vol. 38 No. 3, pp. 349-363.

Rothkopf, D. (2008). Superclass: the global power elite and the world they are making. New York, NY.: Farrar, Strauss and Giroux.

Sklair, L. (2001). The Transnational Capitalist Class. Oxford: Blackwell.

Unruh, G. C., \& Cabrera, A. (2013). Join the global elite. Harvard Business Review.(May).

Wright Mills, C. (1956), The Power Elite, Oxford University Press, Oxford.

Yeoh, B. S. A., \& Willis, K. (2005), "Singaporean and British transmigrants in China and the cultural politics of 'contact zone'", Journal of Ethnic and Migration Studies, Vol. 31 No. 2, pp. 269-285. 